\title{
MODELING OF THE COMPLEX VENTILATION NETWORK RELATED TO LIVEZENI MINE
}

\author{
Eva BIRO ${ }^{1}$, Sorin Mihai RADU ${ }^{2 *}$, Doru CIOCLEA ${ }^{3}$, Ion GHERGHE \\ ${ }^{1}$ E.M. Livezeni, Petroșani, Romania \\ ${ }^{2}$ University of Petroșani, Petroșani, Romania \\ ${ }^{3}$ INCD INSEMEX, Petroşani, Romania \\ ${ }^{4}$ INCD INSEMEX, Petroșani, Romania
}

DOI: $10.2478 / \operatorname{minrv}-2021-0012$

\begin{abstract}
In order to ensure the microclimate conditions for the exploitation of useful mineral substances underground, it is necessary to ensure the control of gas emissions from the field and from the exploited space. For this it is necessary to ensure a balanced air flow at the level of each active mining work in order to dilute the gases. Specialized programs are used to ensure the optimal distribution of air flows at the level of each mining work. The paper presents the modelling and solving of the ventilation network related to Livezeni Mine with the help of the $3 D$ CANVENT program.
\end{abstract}

Keywords: modeling, ventilation, network, CANVENT program, air flow

\section{Introduction}

Mine ventilation is an extremely sensitive and complex domain that includes several disciplines used to accomplish and preserve safe conditions in underground $[1,2,3]$. In this sense, solving the ventilation networks with the help of the calculation technique allows the practitioners to visualize in real time the changes occurred in the network and, what is even more important, they can anticipate the possible disturbances in the ventilation system.

\section{Presentation of the problem}

In order to extract the upper coals underground, it is necessary to carry out a complex of mining works for opening, preparation and exploitation, which require their location both horizontally and vertically. The shape and dimensions of the mining works are different and have free surfaces for the migration of gases from the deposit or from the massif $[4,5]$.

The gases present in the active mining works can be explosive, toxic or suffocating in nature. Additionally, on the alignment of mining works and workplaces, the relative humidity is high and can reach the value of $\mathrm{RH}$ $=100 \%$. At the same time, the thermal gradient manifests itself permanently and leads to an increase in the ambient temperature with depth.

To combat gas accumulations, excessive humidity and heat, the general ventilation system is used, which involves the presence of one or more main ventilation stations located on the surface and which are equipped with two main fans, one of which is active and one is Reserve.

In order to ensure the necessary flows on each active mining work, specialized programs are used, with the help of which the modeling, solving and optimization of the ventilation networks can be performed.

\footnotetext{
* Corresponding author: Radu Sorin Mihai, prof. Ph.D. eng., University of Petrosani, Petrosani, Romania, (University of Petrosani, 20 University Street, sorin_mihai_radu@yahoo.com)
} 


\section{Mine ventilation network}

The ventilation network of Livezeni mine includes three fresh air inlet shafts: Schip shaft, auxiliary shaft, auxiliary shaft no. 3 and two ventilation shafts: east ventilation shaft and ventilation shaft no. 2. It also includes underground mining located on four horizons (horizon 100; horizon 300; horizon 350; and horizon 475). The ventilation network is divided vertically by horizons and horizontally by operating blocks. The whole ventilation network includes 201 junctions (knots) and 267 branches $[6,7,8,9]$.

The connections between the horizons are made by means of shafts, inclined planes or risings. The horizontal connection is made through directional, transverse or diagonal galleries.

The intersection of two works in the ventilation network or the change of direction of a work, defines a node. Mining between two successive nodes, defines a branch.

The ventilation network related to Livezeni mine includes 201 junctions (nodes) and 267 branches [6, 7 , $8,9]$.

\section{Ventilation network modeling}

Internationally, several specialized programs are used to model a ventilation network such as: VentSim, VentGraph, VentPri, Canvent, etc. The specialized 3D Canvent program was used to model the ventilation network for Livezeni mine. This program is based on the use of the Hardy Cross successive approximation method $[10,11,12,13]$.

The solution of the aeration network related to Livezeni mine required certain steps, namely:

a) Identification of nodes on topographic drawings;

b) Identifying the coordinates for each node;

c) Entering the values specific to the coordinates in the program database (fig. 1);

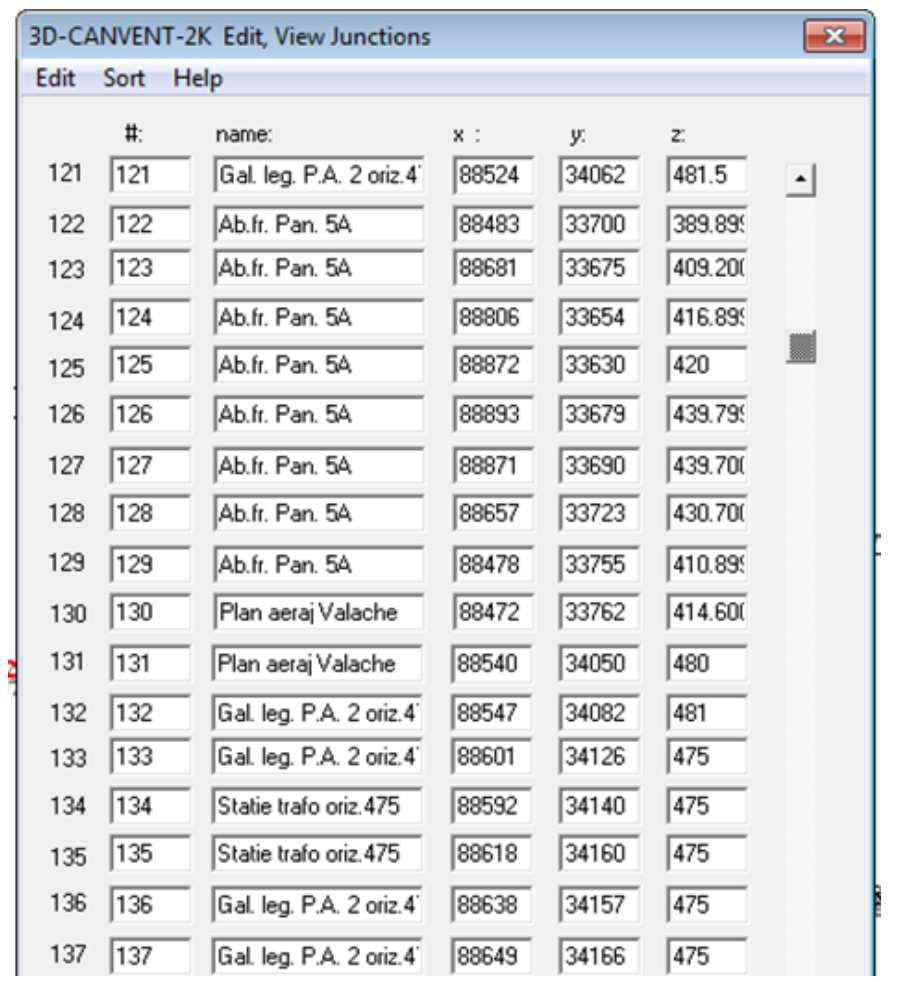

Fig. 1. Nodes - input data

d) Carrying out the measurement campaign which includes:

- measurements regarding the aerodynamic parameters of the mining works;

- measurements regarding the geometric parameters of the mining works;

- measurements regarding the physical parameters of the air.

e) Calculation of the aerodynamic resistances specific to each branch;

f) Entering the values of the parameters specific to the ventilation network, in the database of the specialized program CANVENT (fig. 2); 


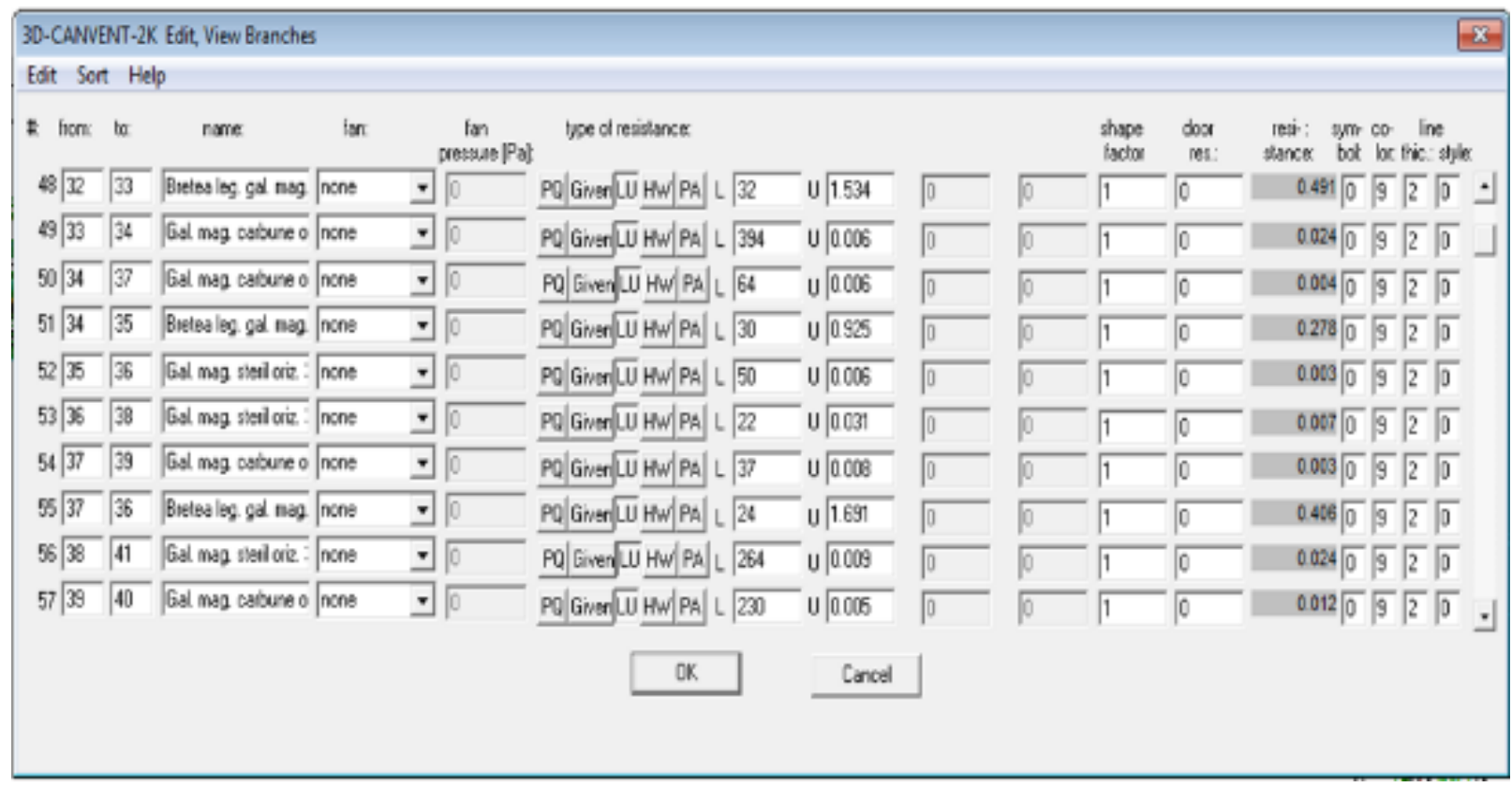

Fig. 2. Branches - input data

g) Data entry for fans (fig. 3.);

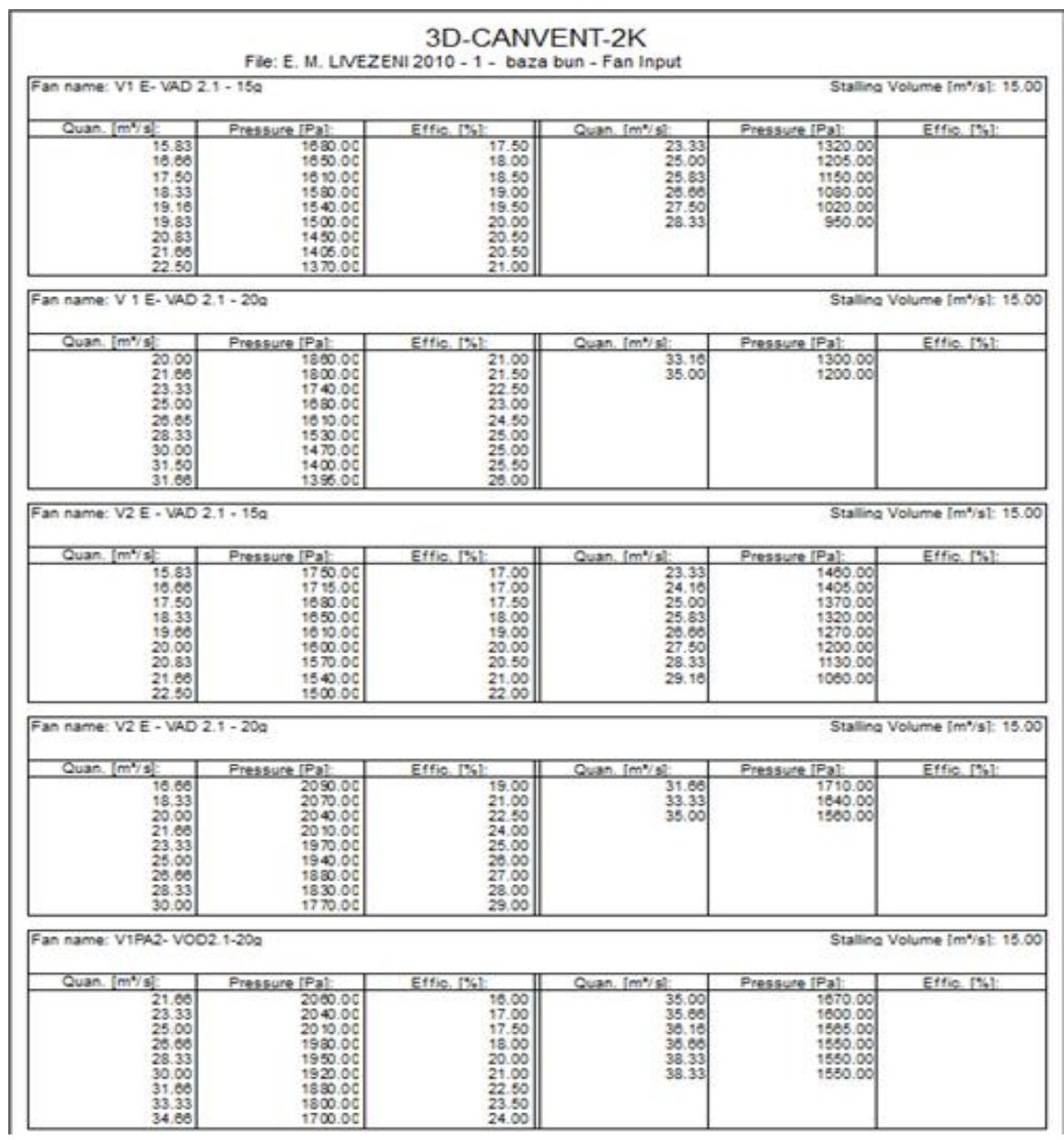

Fig. 3. Fans - input data

h) Representation of the ventilation network, which can be done in a flat system or in a spatial system;

i) Balancing the ventilation network;

j) Solving the ventilation network. This stage provides the values of the air flows on each branch (fig. 4; fig. 5; fig. 6; fig. 7). 


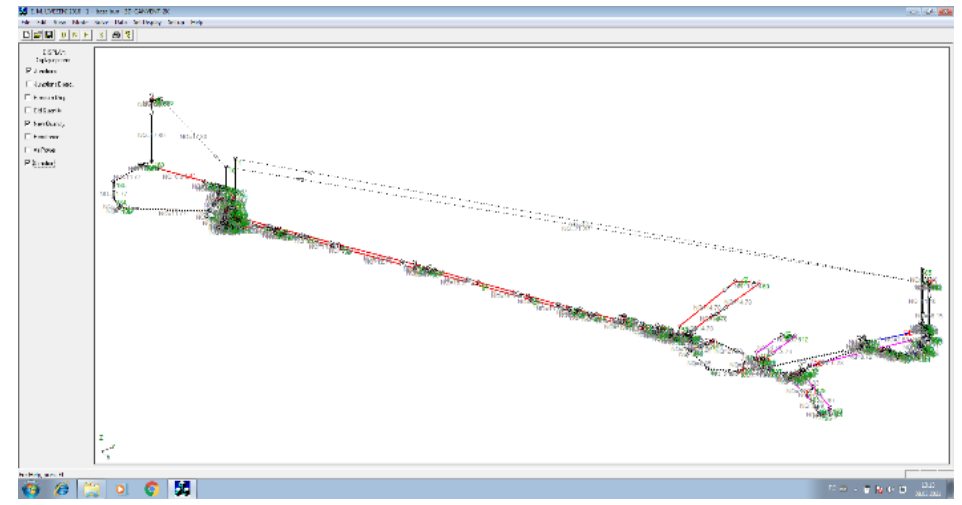

Fig. 4. Livezeni mine ventilation network solved with 3D CANVENT in 3D projection -x-y-z

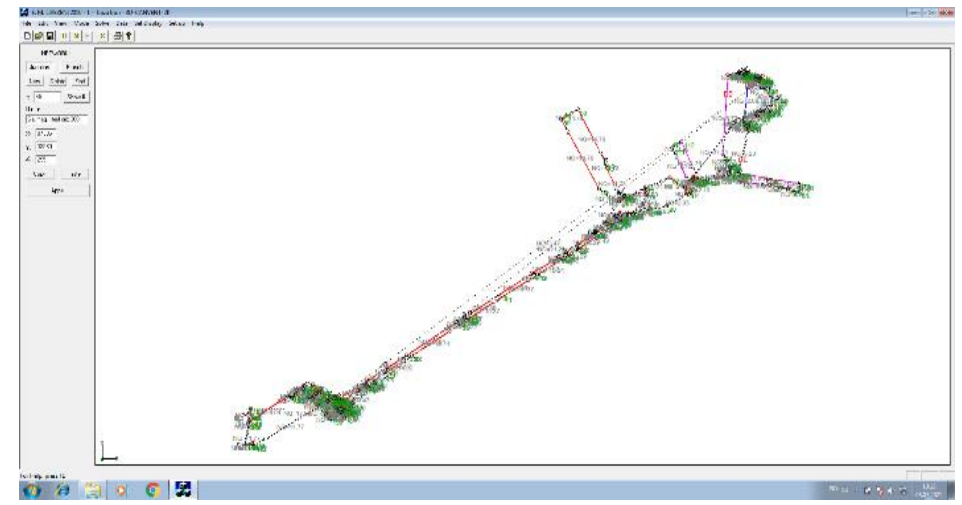

Fig. 5. Livezeni mine ventilation network solved with 3D CANVENT in 2D projection -x-0-y

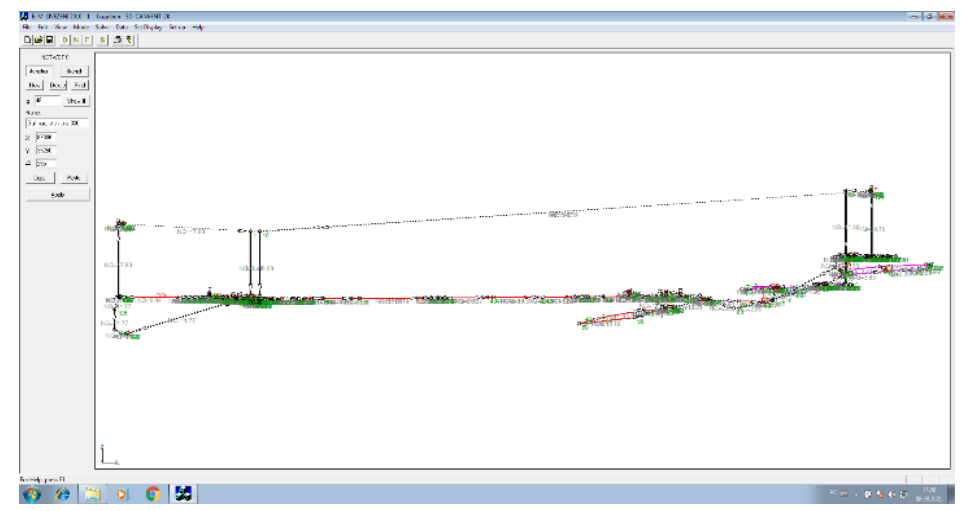

Fig. 6. Livezeni mine ventilation network solved with 3D CANVENT in 2D projection $-\mathrm{x}-0-\mathrm{z}$

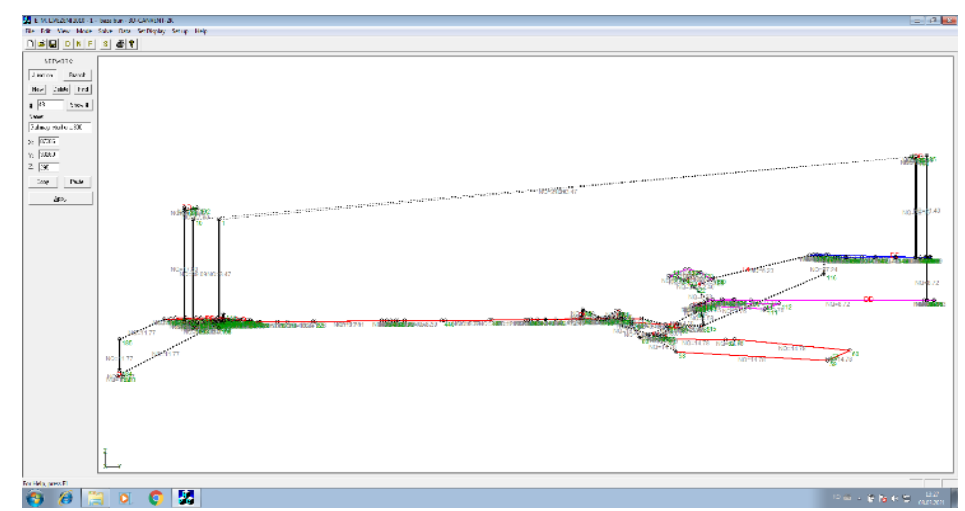

Fig. 7. Livezeni mine ventilation network solved with 3D CANVENT in 2D projection -y-0-z

k) Obtaining the final data. At this stage, access to program data is provided on both electronic and paper support.

The technique presented above allows solving any ventilation networks, regardless of their degree of complexity. 


\section{Ventilation network solving}

After entering all the data regarding nodes, branches and fans, the ventilation network of the mine was solved. The results obtained after solving the ventilation network are presented in fig. 8 for nodes, fig. 9 for branches and fig. 10 for fans.

3D-CANVENT-2K

File: E. M. LIVEZENI 2010 - 1 - baza bun - Junction Results

\begin{tabular}{|c|c|c|c|c|c|}
\hline Juna: & Description: & EnergV|NM/KG]: & Junc.:: & Description: & Energv[NM/KG]: \\
\hline 78 & Plan transport benzi oriz. 300 & -83.92 & 179 & Statie trafo oriz. 300 & -73.72 \\
\hline 79 & Siloz $9 \mathrm{~A}$ oriz. 300 & -89.63 & 180 & Statie trafo oriz. 300 & -74.15 \\
\hline 80 & Plan transport benzi & -93.48 & 181 & Gal. mag. Iscroni oriz. 300 & -74.48 \\
\hline 81 & Plan transport benzi & -312.96 & 182 & Plan transport benzi $300-100$ & -88.97 \\
\hline 82 & Plan aeraj pan. $4 \mathrm{~N}$ & -595.32 & 183 & Plan aeraj str. 13 & -765.44 \\
\hline 83 & Plan aeraj Stanca & -871.90 & 184 & Suitor Hauser & -768.79 \\
\hline 84 & Plan transport benzi siloz 15 & -344.95 & 185 & Suitor Hauser & -779.00 \\
\hline 85 & Put aux 3 & -0.00 & 188 & Plan aeraj str. 15 & -799.25 \\
\hline 88 & $\begin{array}{l}\text { Put aux } 3 \\
\text { Put }\end{array}$ & -2.59 & 187 & Gal. mag. Iscroni oriz. 300 & -800.96 \\
\hline 87 & Circuit Put aux 3 oriz. 475 & -2.99 & 188 & Gal. mag. Iscroni oriz. 300 & -802.96 \\
\hline 88 & Circuit Put aux 3 oriz. 475 & -3.39 & 189 & Put aeraj Est & -815.94 \\
\hline 89 & Circuit Put aux 3 oriz. 475 & -3.79 & 190 & Put aeraj Est & 0.00 \\
\hline 90 & Circuit Put aux 3 oriz. 475 & -3.65 & 191 & Put aeraj Est & -1004.02 \\
\hline 91 & Circuit Put aux 3 oriz. 475 & -4.07 & 192 & Canal Put aeraj Est & 0.00 \\
\hline 92 & Circuit Put aux 3 oriz. 475 & -4.35 & 193 & Put aerai 2 & -0.00 \\
\hline 93 & Put aux. 3 & -3.90 & 194 & Put aerai 2 & -2039.79 \\
\hline 94 & Circuit Put aux 3 oriz. 350 & -5.02 & 195 & Canal Put aeraj 2 & -0.00 \\
\hline 95 & Circuit Put aux 3 oriz. 350 & -6.15 & 196 & Put skip & -2.45 \\
\hline 96 & Circuit Put aux 3 oriz. 350 & -8.95 & 197 & Siloz put skip & -10.73 \\
\hline 97 & Circuit Put aux 3 oriz. 350 & -7.61 & 198 & Siloz put auz. & -8.73 \\
\hline 98 & Gal transv. oriz.350 & -13.40 & 199 & Put aux. & -7.06 \\
\hline 99 & gal diag. oriz. 350 & -338.45 & 200 & Gal. mag. steril oriz. 300 & -74.75 \\
\hline 100 & gal diag. orz. 350 & -359.76 & 201 & Acoes siloz nr.8 & -78.59 \\
\hline 101 & Statie trafo oriz. 350 & -380.07 & & & \\
\hline
\end{tabular}

Fig. 8. Output data nodes

3D-CANVENT-2K

Fie. E. M. LNEZENI2010 baza - Branch Results

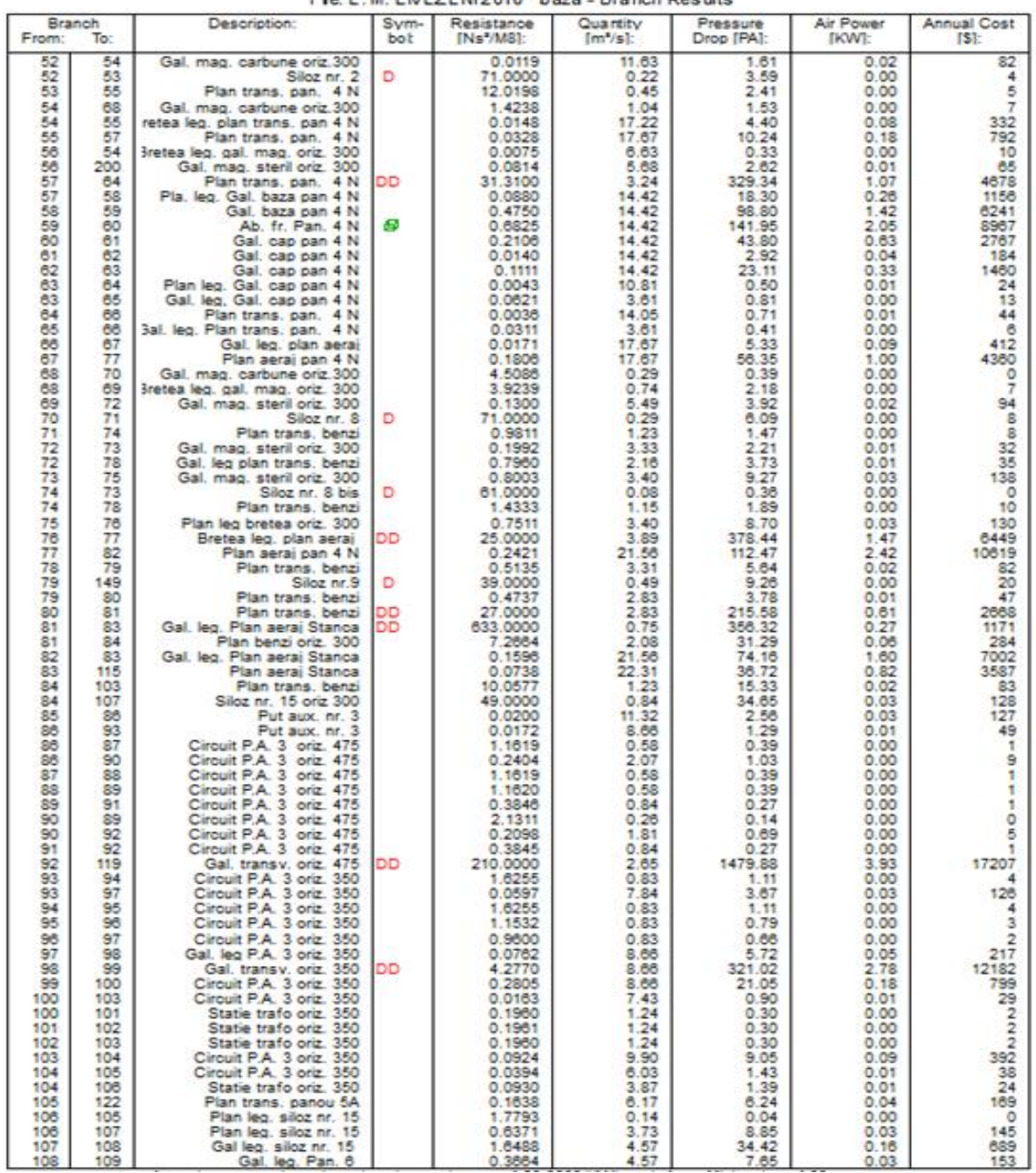

Fig. 9. Output data Branches 
3D-CANVENT-2K

File: E. M. LIVEZENI 2010 baza - Fan Results

\begin{tabular}{|c|c|c|c|c|c|}
\hline Fan Name: & \begin{tabular}{l}
\multicolumn{2}{c}{ Branch } \\
From: ${ }^{2}$ To:
\end{tabular} & $\begin{array}{l}\begin{array}{l}\text { Pressure } \\
\text { [Pa]: }\end{array} \\
\end{array}$ & $\begin{array}{l}\text { Quantity } \\
{\left[\mathrm{m}^{2} / \mathrm{s} \mid:\right.}\end{array}$ & $\begin{array}{l}\text { Air Power } \\
{[\mathrm{KW}]:}\end{array}$ & $\begin{array}{l}\text { Cost } \\
{[\$ 1:}\end{array}$ \\
\hline $\begin{array}{l}\text { V } 1 \text { E-VAD } 2.1-20 \mathrm{a} \\
\text { V2PA2-VOD2.1-25a }\end{array}$ & $\begin{array}{ll}191 & 192 \\
194 & 195\end{array}$ & $\begin{array}{r}1408.37 \\
2123.90\end{array}$ & $\begin{array}{l}31.36 \\
42.35\end{array}$ & $\begin{array}{l}44.11 \\
89.96\end{array}$ & $\begin{array}{l}193198 \\
394009\end{array}$ \\
\hline
\end{tabular}

Fig. 10. Output data fans

Analyzing the ventilation network of Livezeni mine, as well as of the data presented in fig. no. 9, mainly resulted in the following aspects:

- Under the action of the main ventilation Station East, ventilation shafts and Ventilation Station no. 2, a fresh air flow of $53.89 \mathrm{~m}^{3} / \mathrm{s}$ or $3233.4 \mathrm{~m}^{3} / \mathrm{min}$ is introduced underground, distributed as follows:

- oriz. 300: $42.47 \mathrm{~m}^{3} / \mathrm{s}\left(2548.2 \mathrm{~m}^{3} / \mathrm{min}\right)$.

- oriz. $350: 8.74 \mathrm{~m}^{3} / \mathrm{s}\left(524.4 \mathrm{~m}^{3} / \mathrm{min}\right)$.

- oriz. $475: 2.68 \mathrm{~m}^{3} / \mathrm{s}\left(160.8 \mathrm{~m}^{3} / \mathrm{min}\right.$.

TOTAL ENTRY: $53.89 \mathrm{~m}^{3} / \mathrm{s}\left(3233.4 \mathrm{~m}^{3} / \mathrm{min}\right)$.

- Under the action of the depression created by the main ventilation stations, a polluted air flow at mine level is $53.88 \mathrm{~m}^{3} / \mathrm{s}$ or $3232.8 \mathrm{~m}^{3} / \mathrm{min}$ and is evacuated from the underground, distributed as follows:

- Main ventilation station East Ventilation Shaft: $17.80 \mathrm{~m}^{3} / \mathrm{s}\left(1068 \mathrm{~m}^{3} / \mathrm{min}\right)$.

- Main ventilation station Ventilation Shaft No. 2: $36.08 \mathrm{~m}^{3} / \mathrm{s}\left(2164.8 \mathrm{~m}^{3} / \mathrm{min}\right.$.

- The air flow achieved at the level of the main fans was of $70.89 \mathrm{~m}^{3} / \mathrm{s}$ or $4253.4 \mathrm{~m}^{3} / \mathrm{min}$, distributed as follows:

- Main ventilation station East Ventilation Shaft: $28.08 \mathrm{~m}^{3} / \mathrm{s}\left(1684.8 \mathrm{~m}^{3} / \mathrm{min}\right)$.

- Main ventilation station Ventilation Shaft No. 2: $42.81 \mathrm{~m}^{3} / \mathrm{s}\left(2568.6 \mathrm{~m}^{3} / \mathrm{min}\right)$.

- The flow of short-circuited air with the surface at the level of the main ventilation Station East Ventilation Shaft was $10.28 \mathrm{~m}^{3} / \mathrm{s}\left(616.8 \mathrm{~m}^{3} / \mathrm{min}\right)$, and at the level of the main ventilation station Ventilation Shaft No. 2 was $6.72 \mathrm{~m}^{3} / \mathrm{s}\left(403.2 \mathrm{~m}^{3} / \mathrm{min}\right)$.

In fig. 11 and 12 (fan no. 1, Main Ventilation Station Shaft Est), fig. 13 and 14 (fan no. 2, Main Ventilation Station Shaft Est), fig. 15; 16 and 17 (fan no. 1, Main Ventilation Station Shaft no. 2) and fig. 18; 19 and 20 (fan no. 2, Main Ventilation Station Shaft no. 2) are presented the characteristic curves related to the four fans and the resistance curve of the ventilation network at which they operate as a result of solving the mine aeration network Livezeni, by using the 3D-Canvent program.

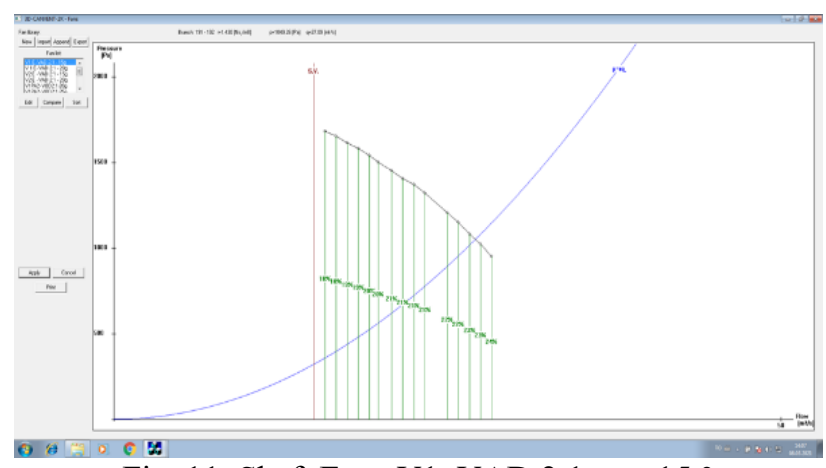

Fig. 11. Shaft East, V1, VAD 2.1, $\alpha=15^{\circ}$

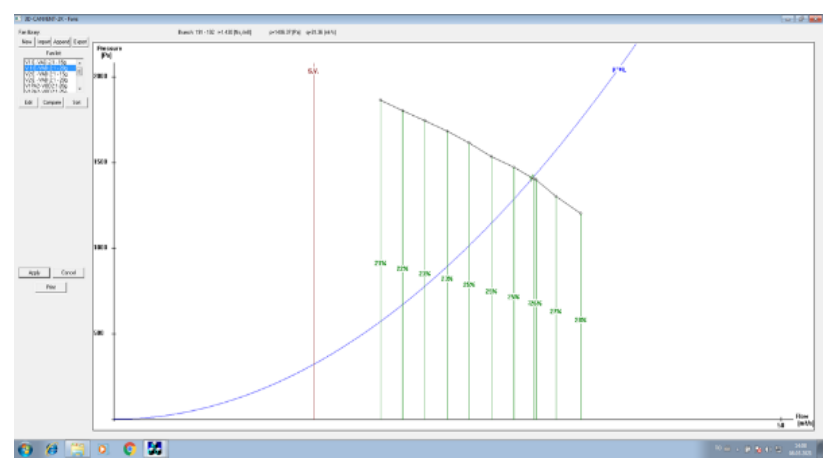

Fig. 12. Shaft East, V1, VAD 2.1, $\alpha=20^{\circ}$

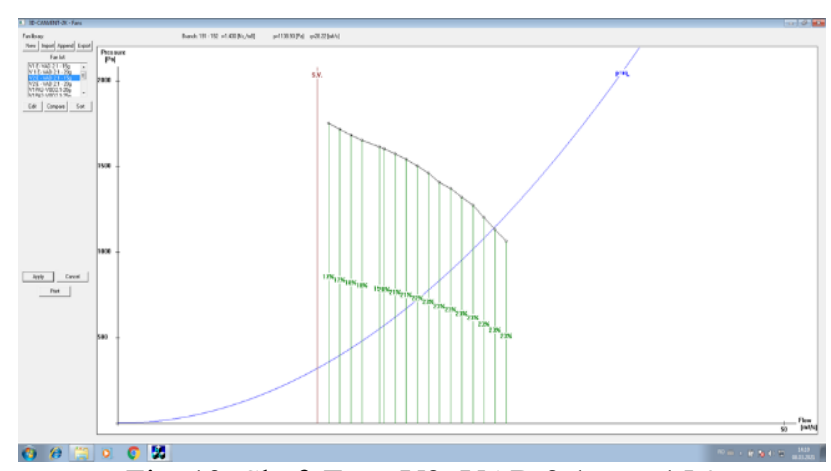

Fig. 13. Shaft East, V2, VAD 2.1, $\alpha=15^{\circ}$

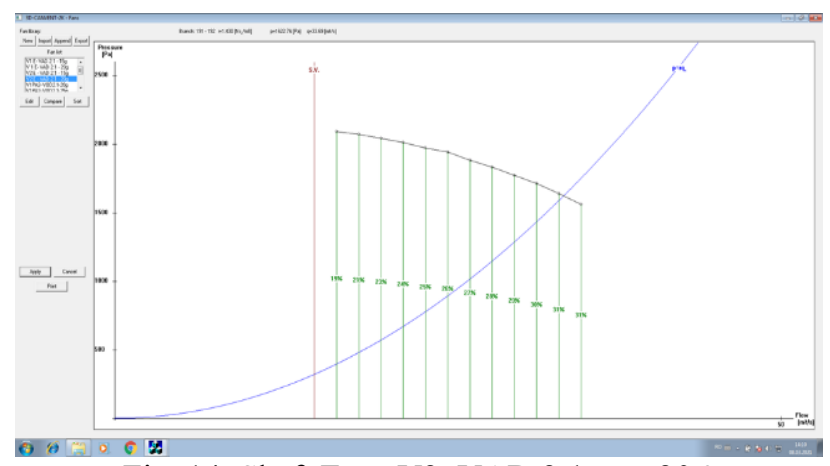

Fig. 14. Shaft East, V2, VAD 2.1, $\alpha=20^{\circ}$ 


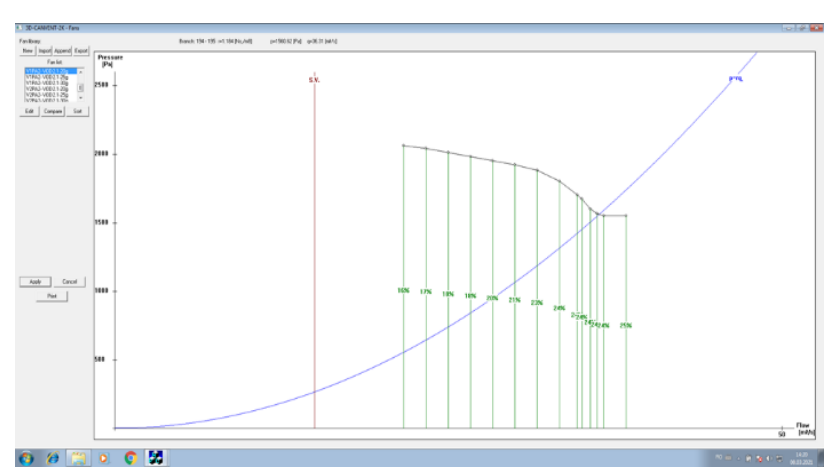

Fig. 15. Shaft nr. 2, V1, VOD 2.1, $\alpha=20^{\circ}$

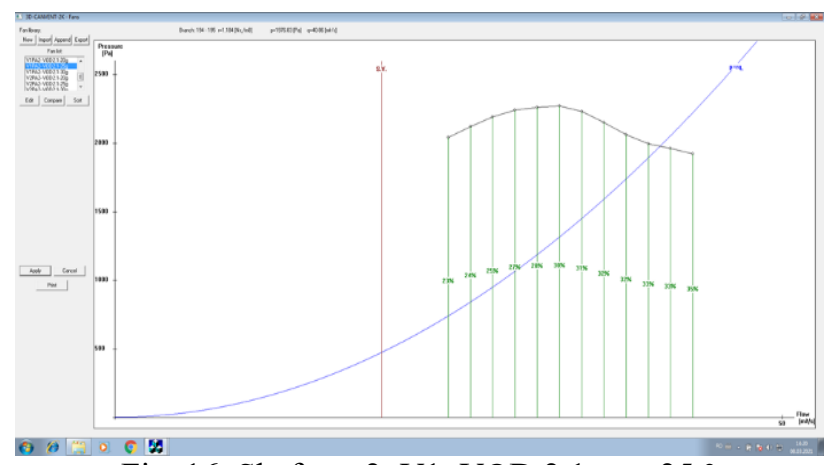

Fig. 16. Shaft nr. 2, V1, VOD 2.1, $\alpha=25^{\circ}$

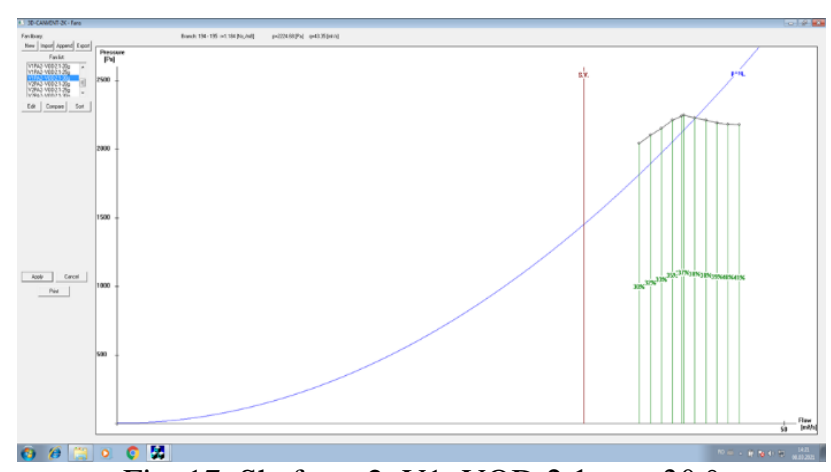

Fig. 17. Shaft nr. 2, V1, VOD 2.1, $\alpha=30^{\circ}$

\section{pp. 6-13}

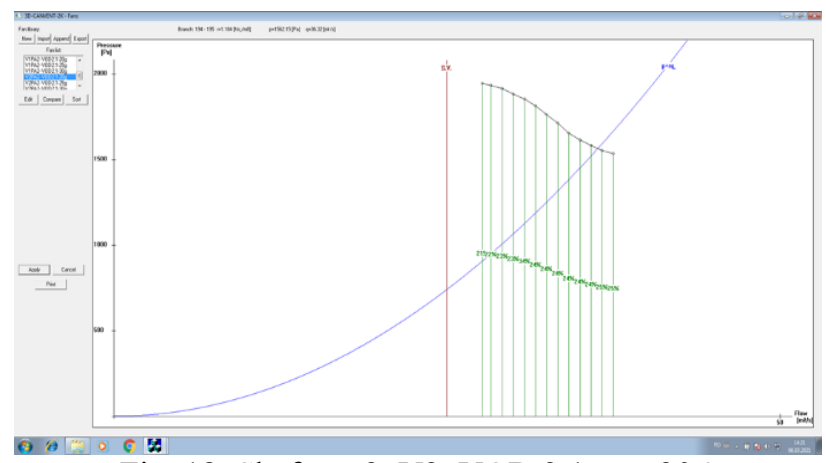

Fig. 18. Shaft nr. 2, V2, VOD 2.1, $\alpha=20^{\circ}$

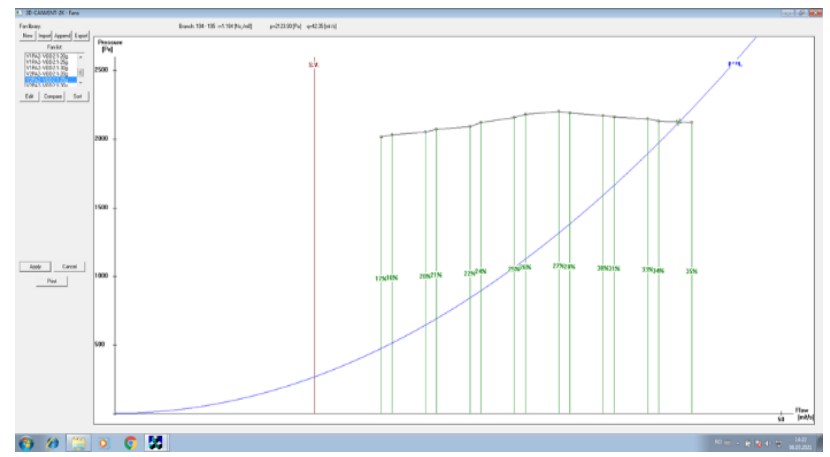

Fig. 19. Shaft nr. 2, V2, VOD 2.1, $\alpha=25^{\circ}$

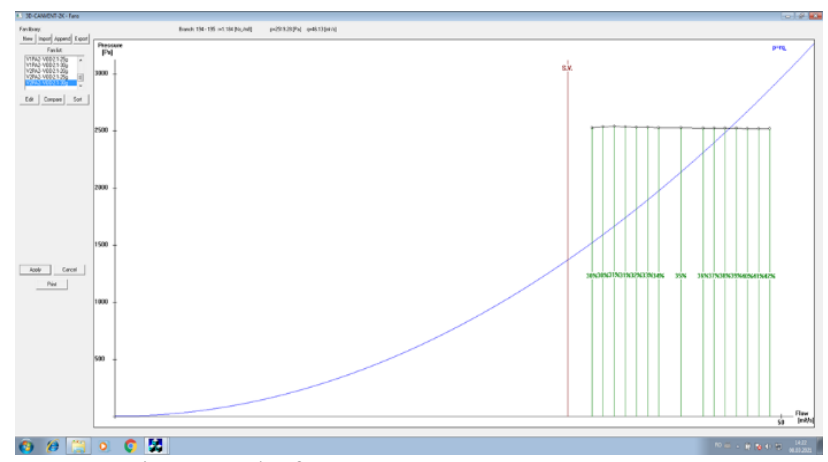

Fig. 20. Shaft nr. 2, V2, VOD 2.1, $\alpha=30^{\circ}$

The last column of fig. no. 9 presents the annual cost of air circulation on each branch of the ventilation network (at an average price of 0.287 lei $/ \mathrm{kWh}$ ), highlighting the following:

- The annual cost of air circulation on the East Ventilation Shaft is 28,065 lei;

- The annual cost of air circulation on the Ventilation Shaft No. 2 is 39,550 lei;

- The annual cost of air circulation at the level of the two East ventilation shafts and ventilation shafts no.

2 is 67,615 lei;

- The annual cost of air circulation on the ventilation plans 15 layer Respectively Stanca is of 1,997 lei respectively 145,332 lei;

- In the case of the ventilation channel of the East Ventilation Shaft, it is of 29,653 lei and on the air short circuit a value of 86,498 lei was registered;

- In the case of the ventilation channel of the Ventilation Shaft No. 2 a value of 45,852 lei was registered and on the air short circuit a value of 114,936 lei was registered.

At the level of the main ventilation station Ventilation Station Shaft Est, the annual cost of air circulation was 265,948 lei, and at the level of the Ventilation Station Ventilation Shaft nr. 2, the annual cost of air circulation was 777,751 lei.

\section{Conclusions}

For the modeling and solving of the ventilation network of Livezeni mine, which has a high degree of complexity, the method of the iterative technique and that of the successive approximations was used, which is the basis of the program for solving the 3D-CANVENT ventilation networks. 
When drawing up the single-wire ventilation scheme related to the mine, the topographic plans for each horizon were used, on the basis of which the nodes and the branches of the networks were established, resulting in a number of 201 nodes and 267 branches.

The 3D - CANVENT program simulates the ventilation systems in operation by taking into account parameters such as: air flows and their distribution in the network, frictional pressure losses, fan performance, energy required for air circulation and the costs involved mining work in the ventilation process.

The elements necessary for running the program, which constitute input data, result from the ventilation monitoring activity, respectively flow and depressiometric measurements performed in underground.

Based on the processing of the results obtained from the measurements performed, the ventilation network of Livezeni mine was modeled and solved. The modeling took into account the distribution in size and direction of flow of air currents.

For the economic characterization of the ventilation process of Livezeni mine, an average energy price of 0.287 lei / $\mathrm{kWh}$ was taken into account in the initial phase.

Under the action of the depression created by the main ventilation installations, a polluted air flow at mine level of $53.88 \mathrm{~m}^{3} / \mathrm{s}$ or $3232.8 \mathrm{~m}^{3} / \mathrm{min}$ is evacuated from the underground;

The annual cost of air circulation in the initial phase at the level of the main ventilation station ventilation shaft Est the annual cost of air circulation was 265,948 lei, and at the level of the main ventilation station ventilation shaft nr. 2, the annual cost of air circulation was 777,751 lei.

\section{References}

[1] Băltăreţu, R., Teodorescu, C., 1971

Mining ventilation and work protection (in romanian), E.D.P. Bucureşti.

[2] Matei, I., Moraru, R, ş.a., 2000

Environmental engineering and underground ventilation (in romanian), Editura Tehnică Bucureşti.

[3] Todorescu, C., Gontean Z., Neag I., 1971

Mining ventilation (in romanian), E.T. Bucureşti.

[4] Almăşan, B., 1984

The exploitation of mineral deposits in Romania (in romanian), E.T. Bucureşti.

[5] Covaci, Ş., 1983

Underground mining (in romanian), E. D. P. Bucureşti

[6] Cioclea, D., 2006

The fixing of the ventilation network based on the depressiometric measurements for establishing the air flows, the depressuring, the aerodynamic resistance, on work fields from E.M. Paroșeni (in romanian), INSEMEX study.

[7] Cioclea, D., 2007-2009

Diminishing the risks generated by explosive environments by using the real time evaluation technique for the ventilation networks for the human protection (in romanian), INSEMEX study.

[8] x x x 1990

Le Roux - Notes on Mine environmental control, The MVS of South Africa

[9] x x x, 2010

Technical documents from E.M. Livezeni (in romanian)

[10] Cioclea, D., 2010-2011

Diminishing the explosion danger within the black coal mines of Valea Jiului by the computer management of the ventilation networks (in romanian), INSEMEX study.

[11] Ianc, N., 2018

Curve determination characteristic to the main ventilation installations Ventilation Shaft 2 and Ventilation Shaft EastBranch E.M. Livezeni (in romanian), INSEMEX study.

[12] Patterson, A.M., 1992

The Mine Ventilation Practitioner's Data Book, M.V.S. of South Africa, 1992.

[13] $\mathbf{x} \times \mathbf{x}$

CANVENT - Mining and Minerals Sciences Laboratories Underground Mine Environment and Ventilation, User's Manual - 3D program - CANVENT - 2K.

This article is an open access article distributed under the Creative Commons BY SA 4.0 license. Authors retain all copyrights and agree to the terms of the above-mentioned CC BY SA 4.0 license. 